\title{
A Survey of Institutional Investors' Attitudes and Perceptions of Residential Property: The Swiss, Dutch and Swedish Cases
}

\author{
Joaquim Montezuma de Carvalho*
}

\begin{abstract}
This paper provides evidence about institutional investors' attitudes and perceptions of residential property as an investment asset group in three European countries (Switzerland, the Netherlands and Sweden). These countries stand out, with an extraordinarily large institutional residential ownership, in fact, residential institutional allocation represents about $6 \%, 2 \%$ and $3 \%$ of the total institutional investment in the Switzerland, the Netherlands and Sweden respectively. Housing is the most important institutional property asset type in Switzerland and the Netherlands, comprising over $52 \%$ and $50 \%$ of their institutional property portfolios respectively. In Sweden residential property plays an important, but not dominant role in the domestic institutional property portfolios, representing about $21 \%$ of the institutional property holdings. Using a postal survey of representatives of pension funds, insurance companies, property investment and asset management companies the study analyses the attractiveness of residential property in terms of institutional investment goals. The survey examines the institutional investors' perceptions of housing investment, namely with respect to its returns, volatility, inflation hedging, liabilities matching and correlation with shares, bonds and non-residential property. Additionally, the survey looks at the institutional investors' experiences regarding the private rented sector.
\end{abstract}

Kew words: Residential property, rental housing markets, institutional investment.

\footnotetext{
•Departamento de Economia, Gestão e Ciências Sociais da Universidade Católica Portuguesa
} 


\section{INTRODUCTION}

This study presents results and conclusions based upon a postal survey of major residential property institutional investors in Switzerland, the Netherlands and Sweden, i.e. pension funds, insurance companies, property investment companies and asset management companies. The study aims to enhance our understanding of the reasons underlying the high residential institutional ownership, providing evidence regarding institutional investors' attitudes and perceptions of residential property as an investment asset group in the three countries. These countries stand out, with an extraordinarily large institutional residential ownership. In fact, residential institutional allocation represents about $6 \%, 2 \%$ and $3 \%$ of the total institutional investment in the Switzerland, the Netherlands and Sweden respectively. Moreover, housing is the most important institutional property asset type in Switzerland and the Netherlands, comprising over $52 \%$ and $50 \%$ of their institutional property portfolios respectively. In Sweden residential property plays an important, but not dominant role in the domestic institutional property portfolios, representing about $21 \%$ of institutional property holdings.

The present study assumes that in order to understand the reasons underlying the involvement of institutional investors in the private rented sector one cannot solely rely on the traditional financial factors: return, risk, diversification and hedge against inflation. The traditional theoretical approach to considering the appropriate allocation to property in mixed asset portfolios is the mean-variance framework. The theory underlying the mean-variance framework considers that asset classes should be selected on expected return and risk for each asset and on the correlation of returns of each and every pair of asset classes (for example, shares, bonds, cash, other types of property). Taking these co-movements into account allows building a mixed asset portfolio that has the same expected return and less risk than a portfolio constructed by ignoring the interactions between asset classes. Empirical studies regarding the role of residential property in mixed asset portfolios suggest that direct residential property not only generates risk-adjusted returns comparable to those on bonds and shares, but also provides low correlations with shares, bonds and non-housing property (e.g. Ibbotson and Siegel, 1984; Hoesli and Hamelink, 1997; and Montezuma, 2004).

The mean-variance framework assumes investors to be fully rational expected utility maximizers. The present study departs from this 
traditional hypothesis, taking into consideration other factors that may also shape the institutional investors behaviour. For instance, prudential habits and "institutional variables" are some of the factors that could also influence institutional decision making. As Kahneman and Tversky (1979) pointed out, in their seminal work on behavioural finance, there are several classes of choice problems that violate the standard consumption-investment models where agents are assumed to be fully rational expected utility maximizers. For instance Clark (1998) following Kahneman and Tversky (1979) suggests that pension fund trustees commonly accept and practice a number of habits of prudence that represent violations of the expected utility theory ${ }^{1}$. According to Clark (1998) these habits minimise the funds risk exposition in the natural context of uncertainty. The first habit of prudence, the loss aversion, states that the disutility of losses is higher than the utility of equal sized gains. The second habit of prudence, the preference for certainty, states that investors give disproportionate weight to eliminating the smallest chance that the investment value will fail. In other words, pension funds tend to be risk-avoiding when it comes to gains, preferring a certain gain to a probable gain even if the expected value of the latter was greater (i.e. hold onto the bird in the hand). The preference for similarity is another prudential habit, whereby the trustees tend to follow the investment strategies of other funds (the bench market). Clark (1998) argues that these habits of prudence help to explain the convention that dominates pension fund investment decisions, namely the avoidance of allocating funds into alternative investments.

Additionally, the institutional investors' decision making process is influenced by "institutional variables" including matching against liabilities, portfolio regulations, accounting standards, tax systems, socially responsible investment, amongst others. This, the nature of institutional liabilities has potential influence on the institutional portfolio allocation strategy. For instance, the duration of liabilities combined with the funding rules determine the assets' duration in which to allocate funds and the resultant interest rate risk. Similarly, the inflation sensitivity of liabilities influences the strategic investment regarding assets' capabilities to hedge against inflation.

Quantitative regulations of portfolio holdings are imposed in several countries and have a clear and widespread influence on portfolios. These regulations exist not only to protect fund beneficiaries or benefit insurers against associated risk, but also to ensure a stable demand for governmental bonds (Davis, 1994). In Switzerland the pension funds face 
ceilings on holding certain assets, such as a 50 percent limit on shares, 50 percent for real estate and 20 percent for foreign assets (Meier 1993 in Davis and Steil, 2001). The Swedish pension funds have been compelled to hold the majority of their portfolio in domestic bonds, debentures and loans to contributors (Davis and Steil, 2001). This could explain to some degree the small allocation to property in the Swedish institutional portfolios ${ }^{2}$. The Dutch private funds appear to be less regulated facing a ceiling of only 5 percent on self investment (Van Loo 1988 in Davis and Steil, 2001). In contrast, the Dutch public pension funds face more strict legal restrictions, limiting them to investing only 10 percent in foreign assets and 20 percent in shares or property. According to Davis (1994) the existing portfolio regulations in Sweden and Switzerland result in high allocations of funds to bonds, despite their poor returns. The regulations also influence the international diversification strategy. For instance, the Dutch private institutions have invested a considerable amount of their portfolios in foreign assets, not only because foreign asset investment restrictions are virtually absent, but also because of the large volume of pension fund assets compared with domestic security and property markets. Conversely, the foreign assets have a less significant presence in the Swiss and Swedish funds due to portfolio regulations.

Strict accounting standards, in Switzerland, limits the investment in shares by funded pension schemes ${ }^{3}$ independently of the existing portfolio regulations discussed previously (Davis, 1994). The same author also points out that Dutch funds hold shares at market value and bonds at book value. This acts as a potential bias against investment in shares.

The taxation system is another factor that could have influence upon the investment strategy. For instance, Bezooyen and Mehta (1998) argue that the Dutch tax system has made investments in bonds relatively more attractive than equities for pension plans.

One can add other "institutional variables" such as the availability of investment opportunities and social awareness. The former institutional variable is especially important in small countries - such as the Netherlands, Switzerland and Sweden - where local financial markets are small, tending to be relatively more illiquid, and where the assets of institutional investors easily exceed the entire domestic equity market. In the same vein, Meer (1990) argues that the large size of Dutch pension funds relative to the capitalisation of the domestic equity market decreases the flexibility of portfolios invested in shares, thus diminishing equity investment attractiveness. 
The survey examines the institutional investors' perceptions of residential property investment, namely with respect to its returns, volatility, inflation hedging, liabilities matching and correlation with shares, bonds and non-residential property. The survey also analyses the attractiveness of residential property in terms of institutional investment goals. In addition, the survey looks at the institutional investors' experiences regarding the private rented sectors in their respective countries. The evidence is based upon the results of a postal survey that targeted the major residential investors in the private rental sector in each of the three countries.

The study is structured as follows: the next section reviews the relevant literature and other recent surveys of institutional investors placing the study in the context of previous relevant work. The background material on the private rented sectors (PRS) in each of the three countries is provided in the third section. In the section four, the research methodology is described and in section five the results of the survey are reported, discussed and compared with previous surveys. Finally the sixth section summarises and concludes.

\section{Private rented sector in Switzerland, the Netherlands and Sweden}

The three main housing tenures in Switzerland and the Netherlands are homeownership and social and private rented. In Sweden there is an additional form of housing tenure with significant importance known as tenant-ownership (co-operative associations).

A comparative analysis of the Swiss, Dutch and Swedish housing systems reveals that there is an interesting similarity between them in terms of tenure. They all have a large rental sector (see table 1), which appears to be related to past government intervention in the form of subsidies and allowances to both the social and private rented sectors and a restrained encouragement of owner-occupation. For instance, the tax regime for home ownership in these countries has been less favourable than in other countries. All three countries apply a tax on imputed rental income, as a corollary to the provision of tax relief on mortgage costs. Additionally, Switzerland and Sweden impose a capital gains tax (see table 1). 
In these affluent countries, the households owning their own home held a minority position, but not necessarily a rich minority meaning that renting is not necessarily a feature of those with lower incomes. In fact, a reasonable proportion of wealthy Dutch and Swiss households live in rented accommodation owned by institutional investors.

Table 1- Cross country housing system summary

\begin{tabular}{|c|c|c|c|}
\hline Housing Tenure $\%$ & $\begin{array}{l}\text { Switzerland } \\
(\text { year 2000) }\end{array}$ & $\begin{array}{l}\text { The Netherlands } \\
\text { (year 2001) }\end{array}$ & $\begin{array}{c}\text { Sweden } \\
\text { (year 1999) }\end{array}$ \\
\hline Owner-occupied & 35 & 53 & 42 \\
\hline Private Rental & 57 & 12 & 17 \\
\hline Social Rental & 3 & 35 & 23 \\
\hline Other tenure & 5 & 0 & 18 \\
\hline $\begin{array}{l}\text { Taxes } \\
\text { Mortgage interest } \\
\text { relief }\end{array}$ & Yes & Yes & Yes \\
\hline $\begin{array}{l}\text { Capital gains exempt } \\
\text { Imputed rental income }\end{array}$ & $\begin{array}{l}\text { No } \\
\text { Taxed }\end{array}$ & $\begin{array}{l}\text { Yes } \\
\text { Taxed }\end{array}$ & $\begin{array}{l}\text { No } \\
\text { Taxed }\end{array}$ \\
\hline Rent Control Design & $\begin{array}{l}\text { The rents for the } \\
\text { unsubsidised } \\
\text { segment reflect } \\
\text { the changes in } \\
\text { costs and interest } \\
\text { rates }\end{array}$ & $\begin{array}{l}\text { The rents for the } \\
\text { high-rental } \\
\text { segment are } \\
\text { liberalized }\end{array}$ & $\begin{array}{l}\text { Tight rent } r \text { controls } \\
\text { persist at all rental } \\
\text { segments }\end{array}$ \\
\hline
\end{tabular}

The mixed provision within the rental sector is, however, significantly different in the three countries. On the one hand there are the Netherlands and Sweden with predominance of social renting and on the other Switzerland with a clear predominance of private renting. In spite of these differences in terms of rental mix provision, the residential rented stock owned by institutional investors has been historically relatively important in all three countries, with remarkable relevance in Switzerland (in 2000, around $16 \%$ of total Swiss stock was owned by institutional investors). The evolution of institutional rental share has been, however, different between them. In Switzerland the rental stock owned by institutions has been rising since 1950, whereas in the Netherlands this type of ownership has been fairly stable (in 1997, around 6\% of total stock) and in Sweden it has been decreasing since the mid 1990s. The divergent evolution of residential institutional ownership seems to be related to different strategies in housing policy. The new housing policy strategy introduced in the Netherlands and Sweden during the beginning of the 1990s established a more residual role for the state in the production, allocation and financing of houses together with progressively more emphasis on home-ownership. The 1990s housing policy strategy together with mortgage market liberalization and the reduction of interest rates led to a relative fall in private rental accommodation in these two countries ${ }^{4}$. It is 
noteworthy that, while in the Netherlands the elimination of supply subsidies to both private and rented sectors was followed by a rent control liberalisation (specially in the high-rental market where the institutional investors are more active) in Sweden the rent controls persisted in all rental categories (low-rental, medium-rental and high-rental). The withdrawal of subsidies and the perpetuation of a highly restrictive rent control together with high land prices and excessive production costs led to a steady decrease of investment in the Swedish private rented sector after the mid 1990s. In contrast, the Swiss unsubsidised market for new contracts has been following a second-generation rent control system, where the rents for sitting tenants reflect the changes in costs (i.e. net annual income, interest rate and operation costs).

\section{Literature Review}

There are not many surveys focused on institutional investor's perceptions of residential property (e.g. Crook et al, 1998; Crook and Kemp, 1999, 2002; Property Research Unit, 1998). Most of the other previous surveys were concerned with investment goals and decisionmaking practices of institutional investors relative to property as an overall asset class. These studies were particularly focused in budgeting techniques and investment goals. Such surveys include Wit (1996) for the Netherlands, Brzeski et al., (1993) for Sweden and the US and Rydin et al., (1990) for the UK. Surveys undertaken in the US include Louargand (1992), Miles et al., (1989), Webb and MacIntosh (1986), Webb (1984), Farragher (1982), Wiley (1976) among others. As Brzeski et al., (1993) point out, these surveys generally show that institutional investors in property have been increasing their reliance on more sophisticated techniques and analyses, consistent with the academic research on property. The literature shows, however, that the adoption of concepts from modern finance in the management of institutional property portfolios has not advanced particularly quickly.

Crook and Kemp (1999) carried out an interview survey, following up a previous survey Crook et al., (1998), to analyse British institutional investor's perceptions of private rented housing and their attitudes towards investing either debt or equity in this sector. The survey involved interviews with 27 senior institutional investor managers. The studies reported that few financial institutions that had already invested in private rental housing, were doing so via direct investment. The organizations 
that were examining the possibility of starting to invest, were, in general, more interested in using indirect investment vehicles. The latter organizations mentioned the lack of suitable investment vehicles (mainly in terms of tax transparency) as an important investment constraint. In addition, the surveys reported that problems like small lot/portfolio size, poor liquidity, low returns ${ }^{5}$, poor quality and high costs of management and maintenance in the private rented sector typified some of the main obstacles to investment in this sector. Interestingly, the participants in the Crook et al., (1998) survey indicated that risks and costs of investing directly in British PRS are substantial compared with investing in other types of property. In a posterior paper Crook and Kemp (2002) explored, using qualitative interviews, the apparent failure of indirect investment vehicles (known as Housing Investment Trusts - HITs) in reviving the UK private rented sector. The research indicates several reasons for that failure. First, HITs are not fully tax transparent. Second, the property value ceilings are too low and make it difficult to achieve well diversified housing portfolios in terms of value. Other reasons include existing trading restrictions, Stock Exchange rules and a lack of large portfolios available to invest in, poor liquidity, and finally discount on net asset value.

The Property Research Unit (1998) undertook an interview survey that sought to examine the likely impact of restricting rent increases in the British regulated fair rent sector on institutions' attitudes to investing in the private rented sector. Twenty seven British institutional investors were interviewed. The list of investors included pension funds, insurance companies, property management companies, property companies and banks. The study concludes that institutional attitudes towards the private rented sector in Britain were changing slowly and those who had decided. to have a positive involvement were less concerned about the possibility of increased regulation in the fair rent sector.

The Immo Survey (2003) conducted by Ernest \& Young AG and Swiss Life Real Estate Partners AG followed up previous surveys on the investment practices of Swiss institutional property investors. Sixty five responses were received from the selected sample (i.e. a $30 \%$ global response rate). The survey reports that the overall property assets represent a substantial proportion of Swiss institutional investors portfolios. The study shows that pension funds and insurance companies prefer to invest directly in the Swiss property markets even though their exposure to indirect property investments is increasing. Moreover, the survey reports that "profitability requirements" (57 mentions) is the most 
important institutional investment strategy factor. This criteria is followed by "geographic boundaries" (38 mentions) and "risk requirements" (38 mentions). Interestingly, "market liquidity requirements" was the least mentioned factor. Additionally, the survey respondents indicate that they primarily diversified by region (over 60\%), type of use $(58 \%$ ) and risk/return $(55 \%)$, while tenant structure, property size and property age were considered to be of secondary importance as diversification factors.

In the fifth section further results from the literature are compared and contrasted with the results of this survey.

\section{Methodology}

The questionnaire was structured around four areas. The first area characterizes the respondent, over-viewing the type of respondents and their overall portfolio size. The second area considers the institutional investment policy. The investment policy issues covered include: the amount allocated to residential property, the composition of property portfolio, past and future residential property investment evolution, type of allocation processes (direct or indirect and investment), institution's chosen market segment (bottom, middle or top end market), source of advice for residential investment (in-house staff, external staff or both), ability to take advantage of the house cycle, and objectives of institutional' both residential and overall portfolio investment strategy. The third area is concerned with the institutional perception of residential property as an investment in a portfolio context. The fourth area analyses the attitudes and experiences regarding the private rented sector.

The sample was designed to include the larger institutional property investors in the surveyed countries. In order to achieve this goal the organisations were selected using specific criteria. They were selected by their inclusion in the main property institutional investors' associations and benchmarks for property investments. Property benchmarks included (Global Property Research a database of listed property companies) for the three countries and the Swedish Property Index (SFI) ${ }^{6}$ for Sweden. Property institutional investors associations include the European Public Real Estate Association (EPRA) ${ }^{7}$ for the three countries and the Association of Institutional property investors in the Netherlands (IVBN) $)^{8}$. To supplement the overall sample, were also included property companies listed in the Swiss, Dutch and Swedish Stock Exchanges, members of Swiss Insurance Association $(\mathrm{SVV})^{9}$, pension funds and insurance companies registered in the website of the Pensions and Insurance Supervisory Authority for the 
Netherlands (Pensioen- \& Verzekeringskamer/PVK), members of Swedish Insurance Federation (Sveriges Forsakringsforbund), pension funds listed by the Swedish Association of Institutions for Retirement Provisions (SIRP) ${ }^{10}$, as well as pension funds listed by the Swiss Federal Statistical Office and, finally, members of the Swedish Investment Fund Association (Fondbolagens Förening). While these lists may not be exhaustive, they are believed to comprise almost the entire population of large portfolios in the pension and insurance community in Switzerland, the Netherlands and Sweden.

A small-scale pilot study was undertaken using a preliminary questionnaire in order that possible defects could be uncover. A draft of the questionnaire was given to a group of seven researchers with experience in survey development and two institutional investors. Rather than asking the test group to simply fill out the questionnaire, participants were asked to comment on their reactions to the questionnaires appearance, formatting, concepts and wording.

The questionnaire was conducted in autumn 2003. It was sent to one hundred leading institutional investors in each of the three countries with a cover letter. The purpose of the cover letter was to describe the goals of the survey and guarantee respondent anonymity. After the questionnaires were mailed by post, follow-up e-mails were sent. One of the disadvantages of postal surveys is that one can not be entirely sure whether the right person answered the questionnaire. The cover letter was directed to the organisations' Chief Investment Officer. One could expect, however, that in some cases the Chief Investment Officer delegated the answering of the questionnaire to someone else within the organisation. Nonetheless, the technical characteristics of our questionnaire and the financial jargon employed in it imply that the respondent has sufficient knowledge of the field of portfolio investment theory and organisation investment strategy to answer the questions accurately. 


\section{Results}

The total respondent pool was thirty seven in all three countries (i.e. a $12 \%$ global response rate), including pension funds, insurance companies, property investment and asset management companies. Our small sample is disappointing but not unexpected, a well known disadvantage of postal surveys is the low response rate. Postal surveys usually generate a substantially lower response rates than interviewed-based surveys. When the response rate is low it is likely that the findings will suffer from the risk of bias. The low response rate and sample bias towards large investment portfolios is not unexpected in our study because institutional residential ownership tends to be concentrated in a small number of large investors. Additionally the self-selection of respondents makes the sample even more biased towards large portfolios. From the total respondent pool, sixteen respondents were from Switzerland (i.e. a 16\% response rate), fifteen from the Netherlands (i.e. a $15 \%$ response rate) and six from Sweden (i.e. a 6\% response rate). Eight responding companies did not have any equity residential property in their portfolio at the end of 2003. Three of those eight organizations without housing holdings are planning to start investing in residential property in the next five years. That is to say that more than $86 \%$ of respondents are currently involved in the private rented sector or are planning to start investing in it.

Clearly, one of the reasons for no response was due to not having investment in the residential private rented sector. The entire population of institutional investors active in PRS is not vast. In actual fact, the institutional residential property assets are concentrated in a relatively small number of institutions ${ }^{11}$. As expected, the Swedish investors had the lowest response rate. As already mentioned, residential is not the most important property investment segment in the Swedish institutional portfolio and its importance has been decreasing since the mid 1990s. The overall response rate although low is still considered to be somewhat satisfactory given the acceptable coverage of the total institutional residential property market in terms of value, and the intense time pressures on the respondent universe of investment officers. The sample even small, represents over 14 billion Euros of residential property in those three countries with a relatively small population ${ }^{12}$. The Swiss institutions in our sample control over 6 billion Euros, representing more than $17 \%$ of the total institutional residential property market value in Switzerland ${ }^{13}$. The Dutch respondents control over 6 billion Euros, representing over $39 \%$ of the total institutional residential property 
market in the Netherlands ${ }^{14}$. The remaining sample's 2 billion Euros are controlled by Swedish respondents, representing more than $17 \%$ of the domestic institutional residential property market ${ }^{15}$. While the estimate of the true response rate is difficult to know since the target population (number of institutional investors holding equity residential property) is not known, we believe that overall sample obtained is reasonably representative of the market in terms of the number of equity residential investment decisions. As Brzeski et al., (1993) highlighted organisations owning larger portfolios make a far greater number of investment decisions than more numerous smaller investors. Taken as a whole, our sample appears to be able to give a reasonable picture of the decision making of residential institutional ownership markets in these three countries in question.

\section{Respondents Characterisation}

The following tables contain information on respondents and their portfolios for the three countries combined. Figure 1 displays the organization type to which the respondents belong (86\% of which are currently involved in the private rented sector or are planning to start investing).

Figure 1 - Type of respondents (all countries)

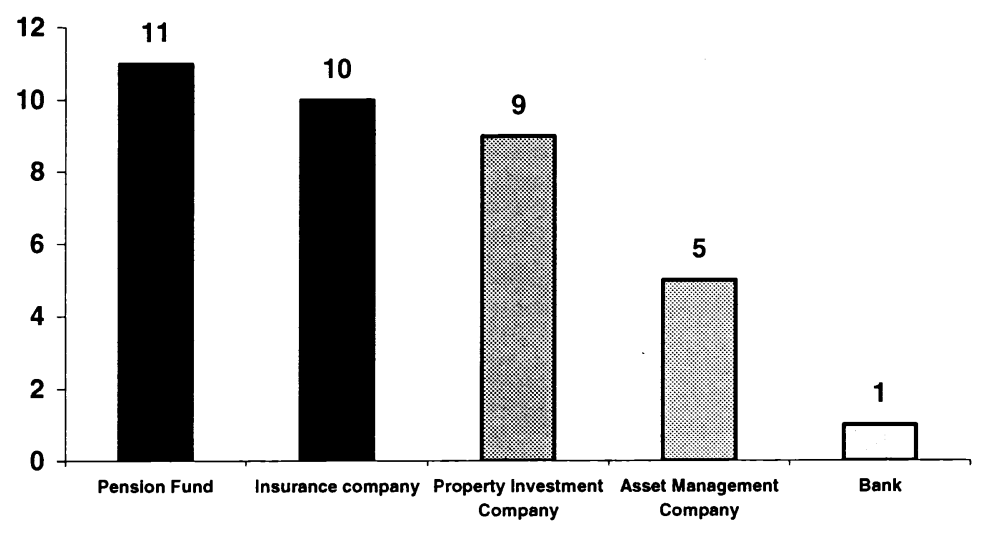

Figure 2 provides a histogram of the size total fund portfolio of the respondents in all countries. The distribution of the total portfolio's value appears to be unimodal and reasonably normally distributed. Almost half 
of the overall respondents have portfolios between one billion and five billion Euros. Over $67 \%$ of the total institutional portfolios are over one billion euros. Almost $21 \%$ of the respondents' portfolios are over five billion euros

Figure 2 - Value of total fund portfolio at year-end 2003 (Euros): all countries

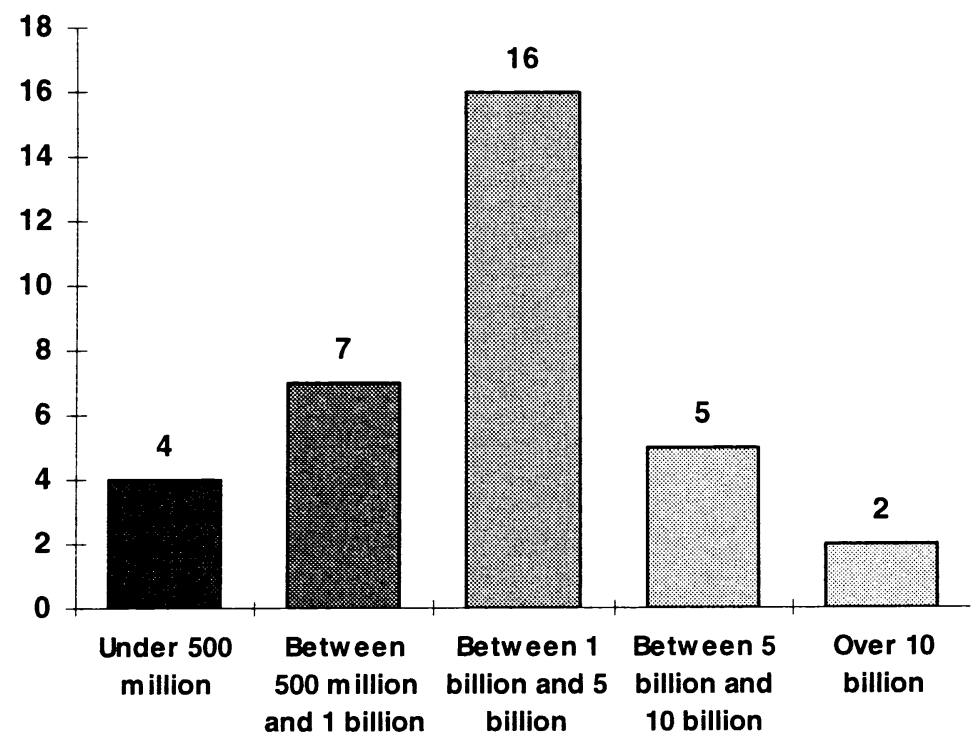

Figure 3 presents a histogram of the size of the residential property portfolios in the three countries ${ }^{16}$. The distribution of the size of the residential portfolio is skewed to the left. This distribution shape is more than likely related to the fact that our sample is biased towards large portfolio size. On the other hand, this shape could also indicate that most of the respondents currently investing in the PRS tend to have large residential portfolios. Over $75 \%$ of the respondents0 residential property portfolios are over one hundred million euros. Only $14 \%$ (4) of the 28 respondents have residential portfolios under 50 million Euros. On the other hand, a significant percentage of the respondents $(28 \%)$ have residential portfolios over one billion Euros. The shape of this distribution seems to corroborate Hoesli and MacGregors (2000) argument that specific risk can only be diversified away in large property portfolios. The authors claim that investors with smaller size property portfolios are subject to higher risk exposure (i.e. both systematic and specific risks) 
and should not hold property. Louargand (1992), alternatively, justifies this distribution tendency by highlighting the barriers of entry to the property market (i.e. divisibility, transactions, search, and agency costs, as well as liquidity).

Figure 3 - Value of residential portfolio at year-end 2003 (Euros): all countries

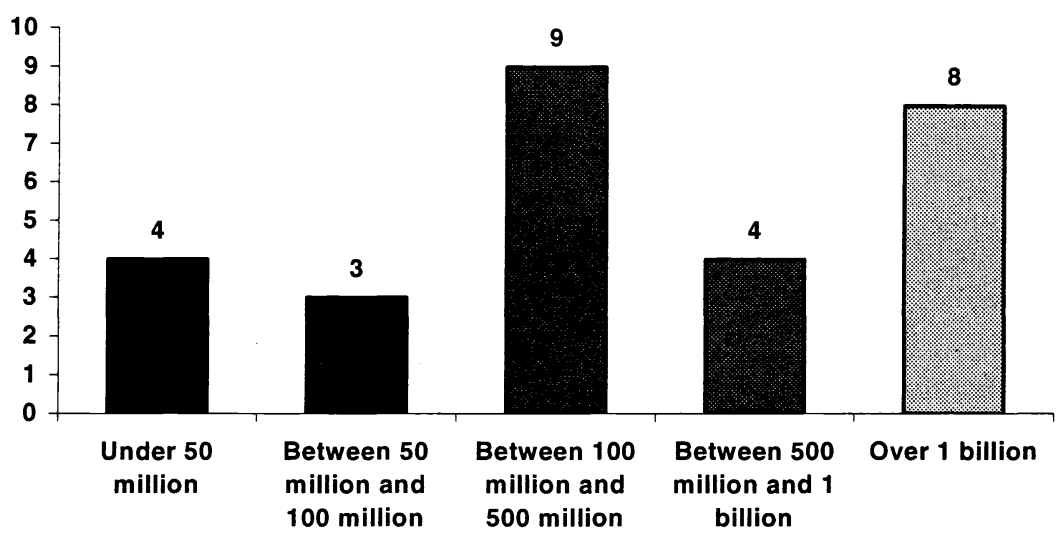

\section{Investment Policy}

Table 2 contains the position by type of property by those respondents that have equity residential property in their portfolios (34 respondents). Not surprisingly, residential is the most popular type of property investment in our sample, with $85 \%$ of respondents investing in residential property. Since the questionnaire was targeted at organizations with a higher probability of having residential property in their portfolios we would expect this bias. Again the self-selection of respondents makes the sample even more biased towards portfolios holding residential property. Office buildings are the second most popular type of investment $(77 \%)$ and land the least popular type of investment $(18 \%)$. A large amount $(86 \%)$ of the respondents with residential property also have offices in their portfolio, whereas the percentage of those having also retail and industrial property is $52 \%$ and $38 \%$ respectively. 
Table 2 - Position by type of property (all countries)

\begin{tabular}{lll}
\hline Property Type & Frequency & Percentage of 34 respondents \\
\hline Housing & 29 & $85 \%$ \\
Office & 26 & $77 \%$ \\
Retail & 18 & $53 \%$ \\
Industrial & 14 & $41 \%$ \\
Land & 6 & $18 \%$ \\
\hline
\end{tabular}

Table 3 and 4 contain the residential investment evolution of institutional investors. The majority of respondents were investing in PRS during the last five years and anticipate that their involvement in the sector will increase over the next five years. The data suggests that organizations overall are not planning to change their past strategy regarding PRS' investment during the next five years.

Table 3 - Evolution of investment in PRS : past and future (all countries)

\begin{tabular}{lll}
\hline Frequency of respondents & Past Five Years & Next Five Years \\
\hline Start to Invest in PRS & 2 & 3 \\
Maintain Investment in PRS & 4 & 7 \\
Increase Investment in PRS & 18 & 20 \\
Decrease Investment in PRS & 5 & 4 \\
\hline Total number of respondents & 29 & 34 \\
\hline
\end{tabular}

None of the Swiss respondents did and will not consider decreasing their investment in PRS (see table 3). In fact, they seem somewhat more optimistic about the future of the sector than their Dutch counterparts. These findings are corroborated by the Immo survey (2003), which states that there is a clear evidence of a commitment to institutional investment in the residential private rented market. 
Table 4 - Investment evolution past and future (the Netherlands and Switzerland)

\begin{tabular}{llllll}
\hline & \multicolumn{2}{c}{ Past Five Years } & Next Five Years \\
\hline Percentage of respondents & Netherlands & Switzerland & Netherlands & Switzerland \\
\hline Start to Invest in PRS & 0 & 2 & 2 & 0 \\
Maintain Investment in PRS & 1 & 3 & 3 & 3 \\
Increase Investment in PRS & 7 & 9 & 6 & 11 \\
Decrease Investment in PRS & 3 & 0 & 3 & 0 \\
\hline Number of respondents & 11 & 12 & 12 & 14 \\
\hline
\end{tabular}

Additionally, the respondents were asked about the percentage of their investment in PRS that was held through direct investment. Table 5 shows that the respondents rely essentially on direct ownership for their investments in the private rented sector ${ }^{17}$. Interestingly, none of the respondents, even the smaller ones, invest in residential property via indirect vehicles exclusively. This disagrees with those who argue that the absence of a suitable indirect investment vehicle (e.g. property investment company, property investment trust, property fund) constitutes a major obstacle to institutional investment in the British private rented sector. Of course, that is not to say that a well structured investment vehicle ${ }^{18}$ is not advantageous to those interested in investing in the private rented sector, particularly for organizations with smaller sized residential portfolios. Nonetheless, it is far from being a pre-requisite to the existence of a residential institutional ownership market.

Table 5 - Direct investment by residential portfolio size - all countries

\begin{tabular}{lll}
\hline Frequency & Between $\mathbf{4 0 \%}$ and $\mathbf{9 0 \%}$ & Over $\mathbf{9 0 \%}$ \\
\hline Under 50 million & 2 & 2 \\
Between 50 million and 100 million & 2 & 1 \\
Between 100 million and 500 million & 1 & 8 \\
Between 500 million and 1 billion & 4 \\
Over 1 billion & 1 & 7 \\
\hline Total number of respondents & 6 & 22 \\
\hline
\end{tabular}

Consistent with our survey, the Immo survey (2003) reports that exposure to indirect investment is overall minor. For instance, in the case 
of the Swiss insurance companies the indirect investment represents only $0.3 \%$ of all of the property investment volume, and in the case of the remaining Swiss institutions around $2.3 \%$ of all of the property investment volume. The Swiss authors argue that domestic insurance companies and larger domestic pension funds give preference to direct investment over indirect investment not so much due to tax leakage problems, but largely because they have a high degree of residential property expertise in-house, which allows them to implement direct investments in the domestic market both effectively and appropriately. Furthermore, the Swiss study states that the increased flexibility, liquidity and diversification are the most important reasons for Swiss organizations to invest indirectly in property, whereas the outsourcing of management tasks and the reduction in the level of complexity of investments are manifestly less significant.

Table 6 - Source of advice for housing investment by residential portfolio

\begin{tabular}{llll}
\hline Frequency & In-house & External Staff & Both \\
\hline Under 50 million Euros & 1 & 1 & 2 \\
Between 50 million and 100 million Euros & 0 & 0 & 3 \\
Between 100 million and 500 million Euros & 2 & 3 & 4 \\
Between 500 million and 1 billion Euros & 1 & 0 & 3 \\
Over 1 billion Euros & 7 & 0 & 1 \\
\hline Total number of respondents & 11 & 4 & 13 \\
\hline
\end{tabular}

size - all countries

Table 6 indicates that the number of organizations relying entirely on external advice for their residential investment is substantially smaller than those relying entirely on in-house advice or both (i.e. in-house and external). Additionally, table 6 suggests a greater reliance upon in-house advice for residential equity investments by larger institutions compared with their smaller counterparts. In fact, seven out of eight of the respondents with residential portfolios over one billion Euros rely only on in-house expertise for their housing investments. This result is consistent with the Immo Survey (2003) argument that larger institutional investors choose to invest in residential property by direct ownership because they have sufficient dimension to have an in-house team with reliable expertise on this specific investment asset group. In this vein, one can say that the 'critical mass' constitutes an important factor for the residential 
institutional ownership. In other words, the residential portfolio size must be large enough in order to justify an in-house team specialized in housing investment, which allows them to invest directly in residential property effectively. It seems reasonable to say that the increase in size and sophistication of the indirect residential investment vehicles will probably change the actual importance of this 'critical mass' factor.

Table 7 shows the main residential private rented market segment in which the organizations are investing in. As one could expect, none of the three countries respondents invest exclusively in the bottom segment of the residential market. The survey indicates that the middle market is by far the most popular segment for all countries.

Table 7 - Main private rented market segment of investment

\begin{tabular}{|c|c|c|c|c|c|}
\hline Frequency & Bottom & Middle & Top & Middle and Top & All segments \\
\hline Sweden & 0 & 2 & 1 & 1 & \\
\hline Switzerland & 0 & 6 & 2 & 4 & 2 \\
\hline Netherlands & 0 & 4 & 3 & 2 & 2 \\
\hline All countries & 0 & 12 & 6 & 7 & 4 \\
\hline
\end{tabular}

Table 8 indicates the responses to the question regarding the organization's ability to take advantage of house price cycles, buying housing stock during periods of market decline and selling when the market rises. Almost $50 \%$ of the overall respondents are able to take advantage of the house price cycle. However, this percentage is not uniform across the three countries. For instance, it appears to be easier for the Swedish and Dutch investors to profit from the housing cycle than their Swiss counterparts. Again, one note of caution must be made in relation to the Swedish case due to the small sample size.

According to some respondents, residential property is set apart from non-residential property by its superior capital gain performance. As a matter of fact, some respondents point out that residential property is expected to perform primarily as a capital appreciation asset whereas non-residential property is expected to perform as an income asset.

One could say that the apparent "speculator" behaviour of institutional investors could in fact, be beneficial to the owner-occupied sector, 
helping to reduce the "natural" house price volatility in the sector. The institutional investors sell housing stock to owner-occupiers (and to other institutional portfolios) when the prices are high, increasing the housing supply a time when it is most needed. Conversely, the institutions buy housing stock (including some that was initially built for the owneroccupied sector) when the prices are low, helping to absorb a possible housing stock surplus. However, empirical research is required to be able to analyse more fully the impact of the "speculator" behaviour of the institutional investors on owner-occupied house price volatility.

Table 8 - Take advantage of house price cycle

\begin{tabular}{llll}
\hline Frequency & Yes & No & Total \\
\hline Sweden & 4 & & 4 \\
Switzerland & 4 & 10 & 14 \\
Netherlands & 6 & 5 & 11 \\
\hline All countries & 14 & 15 & 29 \\
\hline
\end{tabular}

The institutional investors were asked about what goals they had for their residential property holdings. Their answers (see table 9) show that they expect residential property to perform primarily as a total return and a portfolio diversification asset, with inflation hedging and matching against liabilities as less important goals. Total expected return is the highest ranked goal, followed by risk diversification. The cash flow from operations comes third, followed by the potential for appreciation. It is interesting to note that just a small number of respondents in the present survey nominated residential hedge against inflation or match against liabilities as the most important reason to hold residential property. Furthermore, social factors appear to be less influential in the institutional investors' decisions regarding residential property. Moreover, government subsidies (including tax benefits) do not appear to act as an incentive to invest in the PRS.

Similar results were reported by Brzeski et al., (1993), Louargand (1992) and Rydin et al., (1990). They reported that Swedish institutional investors were primarily seeking "long-term real return on equity" for their property investments (all types). The potential for appreciation comes second, followed by "regular return on equity". The importance of hedge against inflation and matching against liabilities were not analyzed in this survey. Louargand (1992) found that the total expected return was the most important institutional goal for property (all types) holdings in the USA, while inflation hedging was seen as less important. Rydin et al., 
(1990) reported that British institutional PRS investors ${ }^{19}$ were above all motivated by the risk-return characteristics of residential property, and much less by its inflation-hedging abilities. Furthermore, the Property Research Unit (1998) asked, both actual and potential institutional investors in the UK, whether they were looking more for capital appreciation, "rental returns" or total return in their investments in residential property. They found that the total return was the most important goal for residential investments, followed by "rental returns".

Table 9 - Goals of institutional investors for residential property - all countries ( $1=$ most important, 5 least important $)$

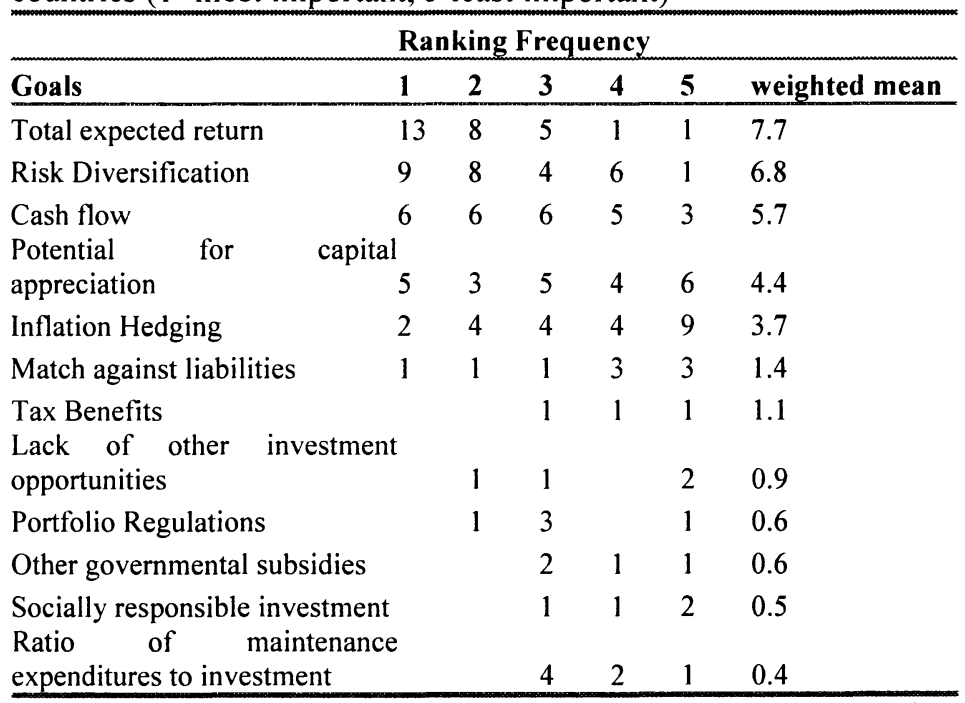

Note: A statistical weight (wi) of 5 was assigned to the most important answers and 1 to the least important. The weighted mean $\mathrm{xw}$

was then calculated by the formula: $x_{w}=\frac{\sum_{i=1}^{5} w_{i} \cdot x_{i}}{\sum_{i=1}^{5} w_{i}}$

Conversely, different results from those pointed out previously regarding the goals of property investment were reported by Wit (1996). The majority of his Dutch interviewees stated that the hedge against inflation was the most important reason to hold property (all types). In 
order to analyse the variation in the goals for residential investment across the countries surveyed table 10 presents the ranking frequency for total expected return and inflation hedging as investment goals for each country. The total expected return seems to be the most popular reason for holding residential assets in all of the countries surveyed. Hedging against inflation as an investment goal, despite being relatively more important for the Dutch organizations than for the Swiss or Swedish counterparts, is not the main reason influencing the Dutch respondents decision to invest in the private rented sector. One possible explanation for the divergence of this findings is that the goals of Dutch investors for residential property are different from those for non-residential property.

Table 10 - Goals of institutional investors for residential property ( $1=$ most important, 5 least important $)$

\begin{tabular}{llllllll}
\hline \multicolumn{7}{c}{ Ranking Frequency } \\
\hline \multicolumn{1}{c}{} & $\mathbf{1}$ & $\mathbf{2}$ & $\mathbf{3}$ & $\mathbf{4}$ & $\mathbf{5}$ & Weighted Mean \\
\hline Total expected return & & & & & & \\
Netherlands & 6 & 4 & 2 & & & 8.7 \\
Sweden & 2 & & 1 & & 1 & 2.5 \\
Switzerland & 5 & 4 & 2 & 1 & & 7.9 \\
\hline Inflation Hedging & & & & & & \\
Netherlands & 2 & & 2 & 2 & 5 & 4.2 \\
Sweden & & 1 & & 1 & 1 & 1.0 \\
Switzerland & & 3 & 2 & 1 & 3 & 3.0 \\
\hline
\end{tabular}

Further, the respondents were asked to rank several of the goals they desired from their overall portfolio investment strategy. Table 11 illustrates that the maximization of expected portfolio returns is by far the most important goal for the respondents. While minimizing the volatility goal, performance relative to one's peer universe and ensuring a real rate of return are ranked at lower level of importance. Moreover, matching plan liabilities or eliminating the smallest chance of a decline in the funds wealth are seen as much less important goals. The institutional investors refer to the preference for similarity (i.e. ensuring performance relative to peer universe) as their most institutional prudential habit. Similar results were reported by Crook and Kemp (2002). Their study indicates that British institutional investors were particularly concerned with performing in line with market benchmarks. Thus, the habit of prudence, the preference for certainty (i.e. eliminating the smallest chance of decline in the funds wealth), appears not to be amongst the core strategic portfolio goals of the respondents in three countries surveyed. 
The results lead to two conclusions. First, the key objectives of asset allocations are to maximize expected returns and minimize the volatility of returns. Second, respondents are not more concerned with protection against inflation or matching against liabilities than with their performance relative to that of their peers. Peer pressure seems to have a significant influence over the respondents' investment strategy. According to Bezooyen and Mehta (1998) in the Netherlands peer pressure is primarily a consequence of the regulation policy enforced by the Insurance Chamber (i.e. the regulatory body for pension funds and insurance companies). The Dutch regulatory body requires an annual report of the plan's funding position, which stresses the investment strategy risk.

Table 11 - Goals of institutional investors for their overall portfolio (1=most important, 5 least important)

\begin{tabular}{lccccccc}
\multicolumn{7}{c}{ Ranking Frequency } \\
\hline Goals & $\mathbf{1}$ & $\mathbf{2}$ & $\mathbf{3}$ & $\mathbf{4}$ & $\mathbf{5}$ & Weighted Mean \\
\hline Maximize expected returns & 22 & 2 & 3 & 2 & 1 & 8.8 \\
$\begin{array}{l}\text { Minimize volatility of returns } \\
\text { Ensure performance relatively to peer }\end{array}$ & 2 & 10 & 8 & 4 & 3 & 5.7 \\
universe & 3 & 4 & 7 & 5 & 5 & 4.5 \\
$\begin{array}{l}\text { Ensure a real rate of return } \\
\text { Keep fund wealth from falling bellow a }\end{array}$ & 4 & 4 & 5 & 4 & 3 & 4.1 \\
$\begin{array}{l}\text { certain level } \\
\text { Match plan liabilities }\end{array}$ & 2 & 4 & 3 & 5 & 4 & 3.3 \\
$\begin{array}{l}\text { Eliminating the smallest change of } \\
\text { funds wealth decline }\end{array}$ & & 2 & 2 & 4 & 2 & 1.6 \\
\hline
\end{tabular}

\section{Institutional Perceptions of Residential Property}

The respondents were asked to compare residential property returns with those on other asset groups (shares, government bonds and nonresidential property). Table 12 suggests that cross-correlations of share returns with those of residential property are believed to be low. Also, non-residential property and bond returns are believed to be mildly correlated with those of residential property. Meaning that residential property is expected to provide diversification benefits for investors even when their portfolios already include non-residential property. Similarly, Crook and Kemp (2002) report that British institutional investors perceive residential property as being able to offer diversification benefits within property portfolios. Besides, residential property, according to the respondents' opinion, is more correlated with inflation than with any other 
asset group analysed. Interestingly, in spite of organizations belief that residential property is a good hedge against inflation, they do not emphasize this housing feature (see table 9) in their goals for investing in PRS.

Table 12 - Correlation of residential property returns with different asset returns and inflation - all countries

\begin{tabular}{|c|c|c|c|c|}
\hline $\begin{array}{l}\text { Percentage } \\
\text { respondents }\end{array}$ & of Shares & $\begin{array}{l}\text { Government } \\
\text { bonds } \\
\end{array}$ & Non-residential property & Inflation \\
\hline \multicolumn{2}{|c|}{ Negative correlated 10} & 3 & 4 & \\
\hline Not correlated & 16 & 12 & 7 & 4 \\
\hline Mildly correlated & 7 & 18 & 20 & 13 \\
\hline Highly correlated & & & 2 & 15 \\
\hline
\end{tabular}

In order to analyse the investors perception about the ability of residential property to match against liabilities, the respondents were asked how residential property performs in matching against liabilities (see table 13). The survey results suggest that housing is perceived to perform well as a match against liabilities, independent of the organization type. Again, our study indicates even though organizations perceive residential property to be a good match against liabilities, they do not consider it as a principal reason to invest in the PRS (see table 9).

Table 13 - Performance of residential property as liabilities matching

\begin{tabular}{|c|c|c|c|c|}
\hline Frequency & $\begin{array}{l}\text { Pension } \\
\text { Funds }\end{array}$ & $\begin{array}{l}\text { Insurance } \\
\text { Companies }\end{array}$ & $\begin{array}{l}\text { Other } \\
\text { organizations }\end{array}$ & $\begin{array}{l}\text { All } \\
\text { Organizations }\end{array}$ \\
\hline \multicolumn{3}{|c|}{ A very good match } & & \\
\hline against liabilities & 1 & 3 & 5 & 9 \\
\hline \multicolumn{5}{|c|}{ A good match against } \\
\hline \multicolumn{5}{|c|}{$\begin{array}{l}9 \\
\text { A fairly good match }\end{array}$} \\
\hline \multicolumn{5}{|c|}{$\begin{array}{l}\text { against liabilities } 1 \\
\text { A bad match against }\end{array}$} \\
\hline $\begin{array}{l}\text { A bad match } \\
\text { liabilities }\end{array}$ & & 2 & & 2 \\
\hline \multicolumn{5}{|c|}{ Total number of } \\
\hline
\end{tabular}

Next, the respondents were asked to compare the risk of residential property with the risk of shares (see table 14). Residential property is, undoubtedly, perceived as an asset group less risky than shares. 
Table 14 - Risk of residential property compared with risk of shares

\begin{tabular}{lllll}
\hline Frequency & $\begin{array}{l}\text { Pension } \\
\text { Funds }\end{array}$ & $\begin{array}{l}\text { Insurance } \\
\text { companies }\end{array}$ & $\begin{array}{l}\text { Other } \\
\text { organizations }\end{array}$ & $\begin{array}{l}\text { All } \\
\text { Organizations }\end{array}$ \\
\hline Much less risky than shares & 4 & 4 & 10 & 18 \\
Less risky than shares & 7 & 5 & 2 & 14 \\
About as risky as shares & & & 1 & 1 \\
Much more risky than shares & & 1 & 1 \\
\hline Total number of respondents 11 & 9 & 14 & 34 \\
\hline
\end{tabular}

The respondents perception about the volatility of housing returns compared with that of shares is consistent with the empirical results presented in table 15, that detail the standard deviation of total returns of these two asset groups in the three countries surveyed (see table 15).

Table 15 - Standard deviation of residential property and share total returns by country

\begin{tabular}{|c|c|c|}
\hline Standard deviation (\%) & Residential property & Shares \\
\hline Switzerland (1987 to 2002 ) & 5.5 & 22.9 \\
\hline Sweden (1984 to 2002) & 7.5 & 29.1 \\
\hline The Netherlands ( 1986 to 2002 ) & 5.1 & 21.0 \\
\hline
\end{tabular}

Source: Montezuma and Gibb (2003)

\section{Institutional Experiences Regarding the Private Rented Sector}

In order to gain a better understanding of the investors perception regarding the problems associated with the private rented sector, the respondents were asked to rank what they considered to be the top five problems in order of importance. These rankings are shown in the frequency table 16 . 
Table 16 - Problems of residential private rented sector - all countries (1=most important, 5 least important)

\begin{tabular}{|c|c|c|c|c|c|c|}
\hline \multirow[b]{2}{*}{ PRS Problems } & \multicolumn{5}{|c|}{ Ranking Frequency } & \multirow[b]{2}{*}{ Weighted Mear } \\
\hline & 1 & 2 & 3 & 4 & 5 & \\
\hline Rent control & 19 & 6 & 3 & 1 & 3 & 8.9 \\
\hline Tenancy regulation & 7 & 16 & 3 & 4 & 3 & 7.9 \\
\hline Poor market information & & 1 & 6 & 7 & 4 & 3.0 \\
\hline Low returns & 1 & 1 & 8 & 4 & 4 & 3.0 \\
\hline Poor liquidity & 4 & 1 & 2 & 2 & 3 & 2.5 \\
\hline $\begin{array}{l}\text { Small lot size and poor } \\
\text { quality }\end{array}$ & 1 & 2 & 2 & 6 & 3 & 2.3 \\
\hline $\begin{array}{l}\text { Transaction costs } \\
\text { Lack of management }\end{array}$ & 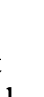 & 4 & 2 & 2 & 6 & 2.1 \\
\hline $\begin{array}{l}\text { Lack of well structured } \\
\text { investment vehicles }\end{array}$ & & 1 & 2 & 3 & 2 & 0.8 \\
\hline
\end{tabular}

The rankings in table 16 seem to indicate that the majority of respondents perceive rent regulation issues (both rent control and tenancy regulation) as being the key problems associated with investing in the private rented sector. Concerns surrounding poor market information comes third (distant), followed by low returns and poor liquidity. Unsurprisingly, the respondents referred to the lack of well structured investment vehicles to be a much less important problem associated with investing in private rented housing, as they tend to invest in housing equity directly (see table 5 ).

\section{Conclusions}

Although few categorical conclusions are possible from a survey such as this, it provides us with an important idea of the character of the institutional residential market character and gives us an indication of institutional investors' perceptions towards residential property equity. Because of the respondents' representativeness in terms of market share, their views can be given some weight and authority. 
The survey suggests that investment in residential property equity is likely to be done through larger portfolios, which tend to invest in housing equity directly. Interestingly, none of the respondents invest exclusively in residential property via indirect vehicles exclusively. Consistent with previous studies, our survey suggests that only a few institutions rely on external advice for residential investment. Overall, this appears to support the idea that 'critical mass' is an important factor for residential ownership.

Furthermore, the survey suggests that residential property is seen mainly as an earning asset group able to provide diversification benefits for investors even when institutional portfolios already include nonresidential property. These results are consistent with a previous study (Montezuma and Gibb, 2003), which concludes that direct residential property in Switzerland, the Netherlands and Sweden has an important role in the optimal allocation of institutional investors with low risk tolerance.

Interestingly, the prudential habit of the institutional investors of preference for similarity is not less important, in terms of overall portfolio goals, than protection against inflation or liabilities matching. Yet, organizations perceive residential property to be correlated with inflation and a good match against liabilities.

The respondents are mainly concerned with rent control and tenancy regulation when investing in the PRS and the lack of well structured investment vehicles is undoubtedly a less important problem.

\section{Acknowledgements}

The author wishes to express his gratitude to all who participated in the survey for their trust and their willingness to answer the questionnaire. It is your interést and candour that have enabled us to conduct this study. I would like to acknowledge Jennifer MacGarrigle for proof reading this paper. The author is grateful to Kenneth Gibb and participants at ERES 2004 meeting for their helpful comments and suggestions. 


\section{Appendix 1 - Questionnaire}

Organization

name:

Interviewee's position within the

organization:

Email

to send the

enquiry

results:

1. Country of respondent:

a The Netherlands

- Sweden

口 Switzerland

2. Is your organization a:

ㅁ Defined Contribution Pension Fund

ㅁ Defined Benefit Pension Fund

ㅁ Life Insurance Company

口 Non-life Insurance Company

口 Property Investment Company

口 Other Investment Company

Other

(please

specify)

3. What is the approximate value of your total fund portfolio?

口 Under 500 million Euros

口 500 million Euros to 1 billion Euros

口 1 billion Euros to 5 billion Euros

口 5 billion Euros to 10 billion Euros

口 Over 10 billion Euros

4. For what types of property are you currently holding an equity position $^{20}$ :
․ Housing
口 Office Buildings
Q Retail
口 Industrial
口 Hotel/Motel
口 Land

Other

(specify) 
5. Do you invest in the residential private rented sector (PRS)?
口 Yes
No (please go to question 13)

6. In the past 5 years your organization had:

口 Started the investment in the private rented sector

口 Maintained the investment in the PRS

口 Increased investment in the PRS ${ }^{21}$

D Decreased investment in the PRS

7. What is the approximate value of your investment in the private rented sector?
U Under 50 million Euros
口 50 million Euros to 100 million Euros
口 100 million Euros to 500 million Euros
口 500 million Euros to 1 billion Euros
口 Over 1 billion Euros

8. Approximately what percentage of your residential property portfolio is invested in:

2. Social housing

3. Non social housing $100 \%$ Total percent percent

9. Approximately what percentage of your investment in the private rented sector is held through:

1. Direct investment $100 \%$ Total

2. Indirect investment (using investment vehicles)__ percent

10. What is your source of advice for equity residential property investment?
a In-house staff
- External Staff
口 Both

11. What is the main residential private rented market segment you invest in?
․ Bottom market (lower quality)
ㅁ Middle market
口 Top end market (higher quality)

12. Is your organization able to take advantage of the house cycle by buying housing stock during the market decline and selling in market rise? 
$\begin{array}{ll}\square & \text { Yes } \\ \square & \text { No }\end{array}$

13. In the next 5 years do you think your organization will:

口 Start to invest in the private rented sector

口 Maintain the actual investment in the PRS

口 Increase investment in the PRS ${ }^{22}$

Decrease investment in the PRS

․ Exit the PRS

14. Please rank your goals or objectives for equity residential property investment (Pick top 5, from $1=$ most important to $5=$ least important)

1. Potential for capital appreciation

2. Cash flow

3. Total expected return

4. Risk diversification

5. Inflation hedging

6. Match against liabilities

7. Tax Benefits

8. Other governmental subsidies

9. Lack of other investment opportunities ${ }^{23}$

10. Accounting standards

11. Portfolio regulations ${ }^{24}$

12. Socially responsible investment

13. Ratio of maintenance expenditures to investment Other (please specify)

15. On the following scale, please show your view on the correlation of equity residential property returns $(1=$ negative correlated; $2=$ not correlated; $3=$ mildly correlated.; $4=$ highly correlated)

1. With stock returns

2. With governmental bond returns

3. With commercial property returns

4. With inflation

16. In your opinion equity residential property is:

口 A very good match against liabilities

口 A good match against liabilities

口 A fairly good match against liabilities

口 A bad match against liabilities

17. In your opinion equity residential property returns are:

a Much less risky than stock return 
ㄴ. Less risky than stock return

口 About as risky as stock returns

口 Somewhat more risky than stock returns

口 Much more risky than stock returns

18. Please rank the following residential private rented sector problems (Pick top 5, from $1=$ most important to $5=$ least important):

1. Rent control

2. Poor market information

3. Low returns

4. Tenancy regulation

5. Small lot size and poor quality

6. Poor liquidity

7. Lack of management expertise

8. Lack of well structured investment residential vehicles

9. Transaction costs

Other (please specify)

19. Please rank the goals or objectives of your overall portfolio investment strategy (Pick top 5, from $1=$ most important to $5=$ least important):

1. Maximize expected returns

2. Minimize volatility of portfolio returns

3. Ensure performance relatively to peer universe (benchmark)

4. Match plan liabilities

5. Keep fund wealth from falling bellow a certain level

6. Ensure a real rate of return

7. Eliminating the smallest chance of fund's wealth decline

Other (please specify)

20. What do you think would contribute to make investment in the private rented sector more attractive 
Additional

comments

Thanks very much for your help. Please return the completed questionnaire by 12 December, 2003 to Joaquim Montezuma, University of Glasgow, Department of Urban Studies, 25 Bute Gardens, G12 Glasgow, UK or by email to: $0110774 \mathrm{~m} @$ student.gla.ac.uk. 


\section{Appendix 2}

Table 17 - Value of residential portfolio at year-end 2003

\begin{tabular}{llccc}
\hline Responses in percentage & \multicolumn{1}{c}{ Switzerland } & Netherlands & Sweden \\
All countries
\end{tabular}

Table 18 - Percentage of direct investment by country

\begin{tabular}{|c|c|c|c|}
\hline & Between $40 \%$ and $90 \%$ & Over $90 \%$ & Tota \\
\hline Sweden & 2 & 4 & 6 \\
\hline Switzerland & 6 & 10 & 16 \\
\hline Netherlands & 6 & 9 & 15 \\
\hline Total number of respondents & 14 & 23 & 37 \\
\hline
\end{tabular}

Table 19 - Main problems of residential private rented sector by country (1=most important, 5 least important)

\begin{tabular}{llllll}
\hline \multicolumn{5}{c}{ Ranking Frequency } \\
\hline Problems & 1 & 2 & 3 & 4 & 5 \\
\hline Rent control & & & & & \\
Sweden & 5 & & 1 & & \\
Switzerland & 5 & 3 & 2 & & 2 \\
Netherlands & 9 & 3 & & 1 & 1 \\
\hline Tenancy regulation & & & & & \\
Sweden & 1 & 3 & & 1 & 1 \\
Switzerland & 3 & 6 & 1 & 2 & 2 \\
Netherlands & 3 & 7 & 2 & 1 & \\
\hline Poor liquidity & & & & & \\
Sweden & 0 & 0 & 0 & 0 & 0 \\
Switzerland & 4 & 1 & 2 & 1 & 1 \\
Netherlands & & & & 1 & 2 \\
\hline
\end{tabular}


There is some consistency about how residential property investments are carried out across the three countries. The majority of the respondents in the surveyed countries clearly prefer the direct investment option (see table 9).

Table 20 - Correlation of residential property returns with those of shares by country

\begin{tabular}{lllll}
\hline & Negative correlated & Not correlated & Mildly correlated & Total \\
\hline Sweden & & 3 & 2 & 5 \\
Switzerland & 4 & 8 & 3 & 15 \\
Netherlands & 6 & 5 & 2 & 13 \\
\hline Total & 10 & 16 & 7 & 33 \\
\hline
\end{tabular}

Table 21 - Correlation of residential property returns with those of government bonds by country

\begin{tabular}{lllll}
\hline & Negative correlated & Not correlated & Mildly correlated & Total \\
\hline Sweden & 1 & & 4 & 5 \\
Switzerland & 1 & 5 & 9 & 15 \\
Netherlands & 1 & 7 & 5 & 13 \\
\hdashline Total & 3 & 12 & 18 & 33 \\
\hline
\end{tabular}

Table 22 - Correlation of residential property returns with those of nonresidential property by country

\begin{tabular}{llllll}
\hline & Negative correlated Not correlated & \multicolumn{3}{c}{ Mildly correlated } & Highly correlated \\
\hline Sweden & 1 & 1 & 3 & & 5 \\
Switzerland & 1 & 4 & 8 & 2 & 15 \\
Netherlands 2 & 2 & 9 & & 13 \\
\hline Total & 4 & 7 & 20 & 2 & 33 \\
\hline
\end{tabular}

Table 23 - Correlation of residential property returns with inflation by country

\begin{tabular}{llllll}
\hline & Not correlated & Mildly correlated & Highly correlated & Total \\
\hline Sweden & 2 & 7 & 3 & 5 \\
Switzerland & 2 & 4 & 5 & 14 \\
Netherlands & 2 & 13 & 7 & 13 \\
Total & 4 & 15 & 32 \\
\hline
\end{tabular}




\section{Notas}

${ }^{1}$ The process of decision making under risk has long been accepted as being modeled by expected utility theory. In this theory decisions are made based on the final asset position of each outcome.

${ }^{2}$ According to Brzeski et al., (1993) Swedish financial institutions often held as little as $1 \%$ of their portfolios in property.

${ }^{3}$ Pension plans where commitments are covered by real or financial assets.

${ }^{4}$ In the Netherlands the decrease of private rented stock resulted mainly from the reduction in individual owners' investment.

${ }^{5}$ It is interesting to note that the British institutions have had opportunity to secure high total returns if they invested in the private rented sector at the survey time. Beneficing from the considerable residential capital appreciation verified since 1999.

${ }^{6} \mathrm{SFI}$ is a key property benchmark organisation in Sweden. The members of this cooperative comprise the leading Swedish property institutional investors.

${ }^{7}$ EPRA's members comprise most of the leading real estate companies and investment institutions in Europe.

${ }^{8}$ Its thirty members include pension funds, insurance companies and share funds that represent approximately $90 \%$ of total Dutch institutional property capital.

${ }^{9}$ The SVV comprises sixty nine members, which represents $98 \%$ of the annual premium revenue in the Swiss insurance market.

${ }^{10}$ The SIRP represents $90 \%$ of the occupational pension plans within the private, cooperative and local government sectors in Sweden.

${ }^{11}$ For instance, the thirty IVBN members control approximately $90 \%$ of the total Dutch institutional property capital. Six of those members do not have residential property holdings.

${ }^{12}$ As Wit (1996) points out the usual low response rate from mail questionnaires, result in very low sample sizes for smaller countries.

${ }^{13}$ IPD and Wuest \& Partner estimated that the total Swiss institutional property market in 2003 was approximately 64 billion Euros, divided 52-48 between residential and non-residential property (http://www.ipdindex.co.uk/about_ipd/locate/swiss.asp).

14 The Association of Institutional Property Investors in the Netherlands (IVBN) estimated that the total Dutch institutional property market in 2003 was 33 billion Euros, divided 50-50 between residential and non-residential property (http://www.ivbn.nl/eng/eng profile.asp).

15 The Swedish Property Federation and NewSec estimated the value of residential property market was 127 billion Euros at end of 2002. The same source estimated that institutions owned 11.43 billion Euros of the Swedish residential market (i.e. $9 \%$ of the total residential market value). The same source estimated that institutional and listed companies owned 42.16 billions in Euros of the Swedish non-residential market (http://www.isa.se/upload/Filer/pdf/RealEstate2003.pdf).

${ }^{16}$ Information by country is provided in table 16 in the appendix 8.2.

${ }^{17}$ Information by country is provided in table 17 in the appendix 8.2. 
${ }^{18} \mathrm{~A}$ well structured investment vehicle must fulfil a number of requirements. Among other things, they need to be tax-efficiency (i.e. not be tax disadvantage compared to direct investments), liquid and have a good management and an appropriate portfolio structure.

${ }^{19}$ The institutional property holdings in Britain are mainly non-residential.

${ }^{20}$ Ownership interest in property (excludes investment in property mortgages).

${ }^{21}$ Allocated more funds to the PRS.

22 Allocate more funds to the PRS.

${ }^{23}$ Relative high size of institutional investors versus equity market capitalization.

${ }^{24}$ For instance portfolio restrictions aimed to prevent over concentration of risk in an asset class. 


\section{References}

Austin, J.J. and Louziotis, D. (1996) Property Rights and Economic Efficiency: A Survey of Institutional Factors, Journal of Real Estate Literature, V.4, pp.137-159.

Bezooyen, J And Mehta, S (1998) 'Investing Strategies for Dutch and UK

Pension Funds', Group of Economic and Market Value Based Studies

Brezeski W J et al (1993) "Institutional Real Estate Investment Practices:

Swedish and United States Experiences", The Journal of Real Estate Research, V.8(3), pp.293-323.

Clark G L (1998) 'Why Convention Dominates Pension Fund Trustee Investment Decisionmaking', Environment and Planning, V. 30, pp. 997-1015.

Crook D and Kemp P (2002) Housing Investment Trusts: A New Structure of

Rental Housing Provision?, Housing Studies, V.15(5), pp. 741-753.

Crook D and Kemp P (1999) Financial institutions and private rented sector, Joseph Rowntree Foundation, York.

Crook D, Hughes J and Kemp P (1998) 'Housing Investment Trusts and the

Returns From Residential Lettings', Journal of Property Research, V.15(30), pp. 229-248.

Crook D, Hughes J and Kemp P (1995) The Supply of Privately Rented Homes, Joseph Rowntree Foundation, York.

Davis P (1994) 'An International Comparison of the Financing of

Occupational Pensions', Special Paper 62, Financial Market Group, London School of Economics.

Gallimore P and Gray A (2002) 'The Role of Investor Sentiment in Property

Investment Decisions', Journal of Property Research, 19(2), pp 111120.

Hartzell, D. and Webb, J. R. (1988) Real Estate Risk and Return

Expectations: Recent Survey Results, The Journal of Real Estate

Research, V.3(3), pp.31-37.

Hoesli, M and Macgregor, B. (2000) Property Investment - Principles and

Practices of Portfolio Management, Longman - Pearson Education Limited, Harlow, England.

Immo-Survey (2003) 'The Investment Behaviour of Swiss Institutional Real

Estate Investors', Swisslife Real Estate Partners and Ernst \& Young, Switzerland.

Jones Lang LaSalle (2000) 'Institutional Investment in the US Residential

Sector, Lessons for the UK?', Residential Research, UK.

Key et al., (2002) 'Towards a European Property Market', IPD European

Property Strategies Conference 2002, London, UK.

Khaneman, D. and Tversky, A. (1979) 'Prospect Theory: An Analysis of

Decision Under Risk', Econometrica,V. 47(2), pp. 263-291. 
Louargand, M. A. (1992) A Survey of Pension Fund Real Estate Portfolio Risk Management Practices, Journal of Real Estate Research, V. 7(4), pp.361-373.

Martin R. and Minns R. (1995) 'Undermining the Financial Basis of Regions: The Spatial Structure and Implications of the UK Pension Fund System', Regional Studies, V. 29(2), pp. 125-144.

Meer, Van Der (1990) 'Investment Strategies Based on Matching', Pensionenen, Uitkeringen en Beleggingen.

Montezuma, J. (2004) 'Housing Investment in an Institutional Portfolio Context', Property Management, V. 22(3), pp. 230-249.

OECD (2001) Institutional Investors Statistical Yearbook.

Property Research Unit, Department of Land Economy, University of Cambridge (1998) Institutional Investors' Attitudes Towards Residential Investment and Prospective Controls on Regulated Rents, Research Report for The British Property Federation.

Rydin, Y, Rodney, W, And Orr, C (1990) 'Why Do Institutions Invest in Property', Journal of Property Finance, V.1(2).

Theresa J. Deamio (ed.) (1983) Approaches to Developing Questionnaires, Statistical Policy Working Paper 10, Office of Information and Regulatory Affairs, Office of Management and Budget, US.

Webb, J. R. (1984) Real Estate Acquisition Rules for Life Insurance Companies and Pension Funds: A Survey, AREUEA Journal, V.12(4), pp.495-520.

Webb, J. R. and McIntosh, W. (1986) Real Estate Investment Acquisition Rules for REITs: a Survey, The Journal of Real Estate Research. V.1(1), pp77-98.

Worzala, E. and Bajtelsmit, V. (1997) Real Estate Asset Allocation and the Decisionmaking Framework Used by Pension Funds Managers, Journal of Real Estate Portfolio Management, V3(1), pp.47-56. 